Article - Agriculture, Agribusiness and Biotechnology

\title{
Effect of Thymol on Soybean Seeds Germination: Physiological and Biochemical Analysis
}

Eduarda Lee Ferreira Lima ${ }^{1}$

https://orcid.org/ 0000-0001-5406-0605

Willian Rodrigues Macedo ${ }^{{ }^{*}}$

https://orcid.org/ 0000-0003-4660-913X

\section{Geraldo Humberto Silva ${ }^{2}$}

https://orcid.org/0000-0001-7928-8980

${ }^{1}$ Federal University of Viçosa - Campus Rio Paranaíba, Institute of Agricultural Sciences, , Rio Paranaíba - MG, Brazi; ${ }^{2}$ Federal University of Viçosa - Campus Rio Paranaíba, Institute of Exact and Tecnological Sciences, , Rio Paranaíba - MG, Brazil.

Received: 2018.05.17; Accepted: 2019.06.13.

* Correspondence: willian_rmacedo@yahoo.com.br; Tel.: +55-34-3855-9480

\section{HIGHLIGHTS}

- Reactive oxygen species (ROS) are an important role in live tissues.

- The phenol compounds to counterattack ROS against damages.

- Low doses of thymol protect and not impair seed vigor.

- Thymol can be considered a technology for seed treatment.

Abstract: Higher levels of reactive species of oxygen are harmful to plant tissues. This study evaluated the action of different doses of thymol on soybean seed germination, biometric analysis and enzymatic parameters; both involved in germination process. High doses of thymol affected the plantlet growth, but not hampered the germination.

Keywords: ascorbate peroxidase; catalase; superoxide dismutase; Glycine max L.; seed vigor. 


\section{GRAPHICAL ABSTRACT}

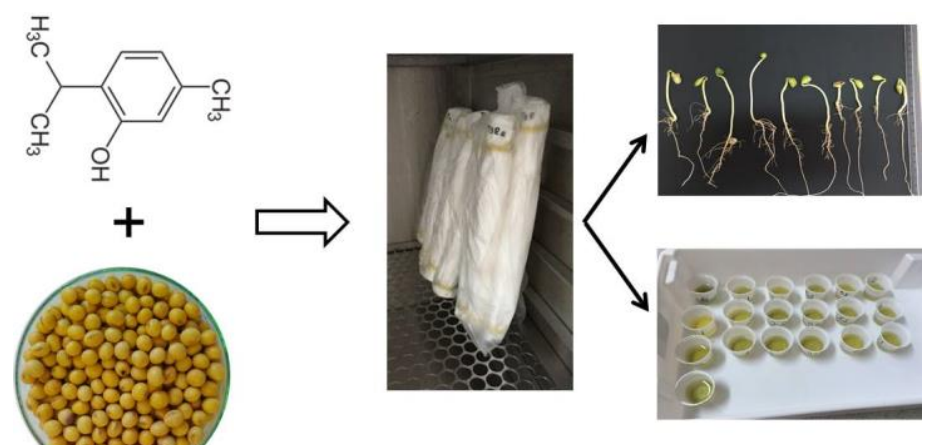

\section{INTRODUCTION}

In order to obtain crops with high yield and productive potential, it is indispensable to use viable seeds to obtain an appropriate stand in the tillage. It is known that seed germination is a complex system, regulated by intrinsic and extrinsic factors [1,2].

The reactive oxygen species (ROS), such as superoxide $\left(\mathrm{O}_{2}{ }^{-}\right)$, hydrogen peroxide $\left(\mathrm{H}_{2} \mathrm{O}_{2}\right)$ and hydroxyl radical $\left(\mathrm{OH}^{-}\right)$, were initially seen only as hazardous compounds, which causes damages to plant cell and tissues, but currently they are also recognized as important molecules in plant biological processes [3]. These molecules are formed by oxidation-reduction reactions and are natural products of the metabolism of all plants, being present in all cells and during all phases of the seed life cycle [1]. In seeds, during dormancy alleviation and germination process, the ROS are relevant molecules for signaling and also has an important roles in endosperm weakening, mobilization of seed reserves, protection against pathogens and programmed cell death [3]. Naturally the plants produce ROS, during photosynthetic process the light produce ROS in chloroplast and peroxisomes, while the dark conditions the mitochondria promote ROS. ROS also occur duo to exogenous factors, such as: salinity, UV radiation, drought, heavy metals, temperature extremes, nutrient deficiency, air pollution, herbicides and pathogen attacks [4].

The ROS are highly reactive and leads to the degradation of the proteins, lipids, carbohydrates and even DNA, which ultimately results in cell death. The stress induced by ROS can be counteracted by enzymatic (catalase, ascorbate peroxidase, superoxide dismutase) and non-enzymatic antioxidants (ascorbic acid, glutathione, tocopherols, carotenoids). Antioxidant substances are responsible for neutralizing free radicals, thus preventing oxidative damage [4].

Bioactive compounds with antioxidant action are the subject of several studies, as a tool to reduce the potential damage of ROS and to benefit germination and vigor of seedlings [5]. One of these compounds is thymol, a phenolic monoterpene, abundantly found in plants of Verbenaceae family, such as Lippia sidoides Cham [6]. It has bactericidal, fungicidal and antioxidant attributes [6,7]. Thus, possibly this compound has potential natural antioxidant action, which can be applied in agriculture through seed protective technology.

The seed germination involves many processes, as the membrane reorganization and reactivation of metabolism, which invariably promote ROS synthesis, these considered detrimental to seed viability [1], and taking into consideration that soybean is the main commodity in Brazil, it is important to recognize potential damages caused for ROS in initial development in this crop, and to seek ways that can avoid economic losses. The aim of this study was to evaluate the thymol action at different doses on germination, biometric and enzymatic parameters involved in soybean germination (Glycine max L.). 


\section{MATERIAL AND METHODS}

The experiment was conducted in the Laboratory of Physiology and Metabolism of Crop Production (LAFIMEPRO) at the Federal University of Viçosa - Rio Paranaíba Campus, in July 2016. Soybean seeds 'TEC 7849 IPRO' were used. The experimental design was completely randomized. The seeds were previously selected, removing those with visible damage, and disinfested with sodium hypochlorite solution $(\mathrm{NaClO})$ at $1 \%$ for five minutes and then washed in running water to remove $\mathrm{NaClO}$ excess.

It was analyzed the use of increasing doses of thymol, with $99 \%$ purity, in the germination process and if it had a regulatory effect on soybean seedlings. The doses of thymol tested were: $0 ; 0.01 ; 0.1 ; 1 ; 10$ and $100 \mathrm{mg} \mathrm{L}^{-1}$, with 4 replicates, these doses were adopted from previous phytotoxicity and cytotoxicity bioassay [8]. It was used rolls of Germitest paper (material free of debris, impurities, fungi and bacteria) as substrate, with 28 $x 38$ centimeters each, previously sterilized and thereafter moistened with each of the 6 different doses of thymol, with 2.5 times its initial weight. 50 seeds were deposited uniformly per roll, totaling 24 rolls and 1200 seeds used.

For germination test, according to the recommendations of the Brazilian Rules for Seed Analysis [9], this test consists in determining in a batch the proportion of live seeds capable of producing normal plants, under favorable conditions. The Germitest paper rolls were kept in a Mangelsdorf germinator, set at $25 \pm 0.5^{\circ} \mathrm{C}$, for 7 days, for germination analysis. It was considered all the 50 seeds per replicate per treatment. The results were expressed in percentage (\%).

The germination speed index (GSI) consists of the evaluation of germination speed. The faster the germination, the greater it is vigor. To obtain this index the evaluations were performed concomitantly with the germination test, daily counting the numbers of germinated seeds from 4th day and calculating the rate of germination speed according to the equation [10]:

$$
\mathrm{GSI}=\frac{\mathrm{E}_{1}}{\mathrm{~N}_{1}}+\frac{\mathrm{E}_{2}}{\mathrm{~N}_{2}}+\frac{\mathrm{E}_{3}}{\mathrm{~N}_{3}}+\frac{\mathrm{E}_{\mathrm{n}}}{\mathrm{N}_{\mathrm{n}}}
$$

Where: $\mathrm{E} 1, \mathrm{E} 2, \mathrm{En}=$ normal seedlings counted in the first, second and last counting; N1, $\mathrm{N} 2, \mathrm{Nn}=$ number of days on first, second and last counting [10].

On the 7th day of the experiment's implementation, biometric measurements of shoot and root length were performed on 10 subsamples of each paper roll, randomly chosen, using a millimeter ruler. The results were expressed in centimeters $(\mathrm{cm})$.

For quantification of antioxidant enzymes activity, we evaluated the activity of three important antioxidant enzymes were quantified according to authors: superoxide dismutase (SOD) [11,12], catalase (CAT) [13,14] and ascorbate peroxidase (APX) [15]. Both assays were submitted to reading in spectrophotometer UV-Vis Evolution 300 (Thermo Fisher Scientific, Germany).

The values observed in the experiment treatments were submitted to ANOVA and the means were compared by Dunnett's test, at $5 \%$ of significance [16].

\section{RESULTS}

It was observed that the germination of soybean seeds and the GSI after the application of thymol, under highly favorable conditions of temperature and humidity, showed no significant effect (Table 1). For biometric parameters we observed significant effect in the shoot and root measurement of the seedlings (Table 1), onto both variables presented reduction in the length when applied the doses of 10 and $100 \mathrm{mg} \mathrm{L}^{-1}$, where for the root a decrease was observed in the order of 78.23 and $68.12 \%$, respectively, and for shoot we observed reduction of 84.72 and $34.02 \%$, respectively, there was a more abrupt decrease if compared to the others doses. Our results showed the great sensibility in shoot length when subjected to doses of thymol. 
Evaluating oxidative stress in plant tissues we observed no significant effects for thymol on the activity of CAT and APX, these samples presented high variability, with high CV (\%) values. These enzymes can be considered key in the scavenger to the hydrogen peroxide, but thymol showed effective action in the regulation of superoxide anion $\left(\mathrm{O}_{2}{ }^{-}\right)$, by significant reduction in the SOD activity, with exception of the $1 \mathrm{mg} \mathrm{L}^{-1}$ dose, that did not differ from the control (Table 1).

Table 1. Means of germination percentage, germination speed index (GSI), shoot length, root length and superoxide dismutase (SOD) activity in soybean seeds subjected to different doses of thymol.

\begin{tabular}{lccccc}
\hline $\begin{array}{l}\text { Dose } \\
\left(\mathbf{m g ~ L}^{-1}\right)\end{array}$ & $\begin{array}{c}\text { Germination } \\
(\%)\end{array}$ & GSI & $\begin{array}{c}\text { Shoot lenght } \\
(\mathbf{c m})\end{array}$ & $\begin{array}{c}\text { Root lenght } \\
(\mathbf{c m})\end{array}$ & $\begin{array}{c}\text { SOD } \\
\left(\mathbf{U ~ m i n}^{-1} \mathbf{~ m g}^{-1} \text { protein }\right)\end{array}$ \\
\hline 0 & $88.5( \pm 2.5)$ & $22.35( \pm 0.54)$ & $8.47( \pm 0.21)$ & $12.77( \pm 1.38)$ & $1.44( \pm 0.22)$ \\
0.01 & $86.5( \pm 1.5)$ & $21.56( \pm 0.48)$ & $6.66( \pm 0.23)^{*}$ & $11.10( \pm 0.80)$ & $1.05( \pm 0.49)^{*}$ \\
0.1 & $87.5( \pm 1.7)$ & $21.96( \pm 0.50)$ & $7.96( \pm 0.66)$ & $11.80( \pm 0.72)$ & $0.75( \pm 0.11)^{*}$ \\
1 & $85.5( \pm 3.6)$ & $21.53( \pm 0.86)$ & $6.17( \pm 0.29)^{*}$ & $10.86( \pm 0.40)$ & $2.07( \pm 0.43)$ \\
10 & $85.5( \pm 1.3)$ & $21.34( \pm 0.28)$ & $2.60( \pm 0.14)^{*}$ & $2.78( \pm 0.30)^{*}$ & $0.22( \pm 0.06)^{*}$ \\
100 & $93.5( \pm 2.8)$ & $23.38( \pm 0.60)$ & $2.83( \pm 0.34)^{*}$ & $4.07( \pm 0.27)^{*}$ & $0.95( \pm 0.27)^{*}$ \\
\hline
\end{tabular}

The means were compared at Dunnett's test, at $5 \%$ of significance, ${ }^{*}$ differences significant. For germination, GSI, shoot and root lenght $(n=4)$, and for SOD $(n=3)$.

\section{DISCUSSION}

Our results indicate that during the initial process of soaking and emission of the radicles, thymol did not cause deleterious effects and phytotoxic responses. Similar response was found in research with kojic acid and tyrosol, two potent antioxidants, and no harmful effects have been observed on germination of wheat seeds (Triticum aestivum $\mathrm{L}$.) [5]. Still, in studies with lettuce seeds (Lactuca sativa L.) the authors observed $95 \%$ of germination when applied $0.001 \%$ and $0.01 \%(\mathrm{v} / \mathrm{v})$ of $L$. sidoides essential oils (thymol-rich compound), but when the concentrations increased to $0.1 \%$ and $1 \%$, the germination rate was $0 \%$, this essential oil was obtained from leaves of matured plants and extracted by hydrodistillation [17]. Many allelochemical compounds have both inhibitory and stimulatory attributes effects, according to the doses of these molecules and also the recipient species $[5,18,19]$. Generally the monoterpenes (eg.: thymol) present allelopathy activity, with deleterious effect on cell cycle, with reduction in seed germination and plant development [8], we consider that the absorption and the consequent translocation in the vascular system led to the accumulation of thymol in the shoot tissues, which led to the allelophatic activity in the plant shoot. According to AOSA [20], the seedling length or part of it, is an important information related to vigor tests. The use of the compound, mainly at the higher concentrations, inhibited seedling growth, which possibly can be explained by the residual effect of thymol on the radicle during the time of absorption of the compound present in substrate, promoting anomalous growth in shoot and root, and also delaying its development.

The detection of enzymatic activity indicates that there is production of ROS, and therefore the plant is working to remove them through these enzymes. At dose 0 , the SOD activity was intense, but when submitted to the presence of thymol, the activity became low, we note reductions of $27.08 \% ; 47.91 \% ; 84.72 \%$ and $34.02 \%$, for the doses of: $0.01 ; 0.1$; 10 and $100 \mathrm{mg} \mathrm{L}^{-1}$, respectively. Our data suggest that thymol is a potent scavenger of ROS and so there is no metabolic expenditure for the synthesis of enzymatic protection mechanisms. All components of a cell are susceptible to the action of ROS, however, the membrane is highly voluble because it undergoes intense peroxidation, which generates alterations in membrane structure and its permeability [4]. Antioxidant compounds are responsible for protecting the lipid layer of cell membranes against oxidation caused by free radicals, although recent investigations have shown that the process can accelerate the oxidation and degradation of other molecules, such as DNA [21]. 
From a holistic analysis it is possible to verify that thiol compound, via seed treatment, promote a controlled endogenous ROS production, we observed that the low activity of SOD (10 and $100 \mathrm{mg} \mathrm{L}^{-1}$ ), led to the significant increase of the damage in the seedlings, reducing their growth of shoot and root. While lower doses do not impair the development of the plant, especially its root system.

In relation to sanity, we observed that the Germitest paper towel rolls soaked with high concentration of thymol were the least contaminated by pathogenic microorganisms, adducing the antiseptic, antifungal and bactericidal attributes, for which thymol is also known (Supporting Material 1).

\section{CONCLUSION}

In conclusion, the use of the doses of thymol in seed treatment, by soaking, did not impair the germination and the GSI of soybean seeds. But the use of high doses affected the seedling phenotype; doses up to the $1 \mathrm{mg} \mathrm{L}^{-1}$ of thymol showed deleterious effects on root and shoot seedlings. We recognize thymol as a potential protective action for soybean seeds treatment.

Funding: Please add: This research was funded by National Council for Scientific and Technological Development (CNPq, Conselho Nacional de Desenvolvimento Científico e Tecnológico), National Institute of Science and Technology - INCT BioNat, grant \# 465637/2014-0, Brazil and FAPEMIG, grant number CAG-APQ-00560-16.

Conflicts of Interest: The authors declare no conflict of interest

\section{REFERENCES}

1. Kumar, S.P.J.; Prasad, S.R.; Banerjee, R.; Thammineni, C. Seed birth to death: dual functions of reactive oxygen species in seed physiology. Ann Bot. 2015; 116: 663-668. doi:10.1093/aob/mcv098 2. Ferrarese, M.L.L.; Baleroni, C.R.S.; Ferrarese-Filho, O. Effects of fatty acids on carbohydrates and lipids of canola seeds during germination. Braz. Arch. Biol. Technol. 1998; 41. doi.org/10.1590/S1516-89131998000300007

3. Gomes, M.P.; Garcia, Q.S. Reactive oxygen species and seed germination. Biologia. 2013; 68 : 351-357. doi:10.2478/s11756-013-0161-y

4. Gill, S.S.; Tuteja, N. Reactive oxygen species and antioxidant machinery in abiotic stress tolerance in crop plants. Plant Physiol Bioch. 2010; 48: 909-930. doi:10.1016/j.plaphy.2010.08.016

5. Macedo, W.R.; Silva, G.H.; Santos, M.F.C.; Oliveira, A.P.S.; Souza, D.S. Physiologic and metabolic effects of exogenous kojic acid and tyrosol, chemicals produced by endophytic fungus, on wheat seeds germination. Nat Prod Res. 2017; 1-5. doi:10.1080/14786419.2017.1374261

6. Lemos, T.L.G.; Matos, F.J.A.; Alencar, J.W.; Craveiro, A.A.; Clark, A.M.; McChesney, J.D. Antimicrobial activity of essential oils of Brazilian plants. Phytother Res. 1990; 4: 82-84. doi:10.1002/ptr.2650040210

7. Trevisan, M.T.S.; Marques, R.A.; Silva, M.G.V.; Scherer, D.; Haubner, R.; Ulrich, C.M.; Owen, R.W. Composition of essential oils and ethanol extracts of the leaves of Lippia species: identification, quantitation and antioxidant capacity. Rec Nat Prod. 2016; 10: 485-496.

8. Pinheiro, P.F.; Costa, A.V.; Alves, T.A.; Galter, I.N.; Pinheiro, C.A.; Pereira, A.F.; Oliveira, C.M.R.; Fontes, M.M.P. Phytotoxicity and Cytotoxicity of Essential Oil from Leaves of Plectranthus amboinicus, Carvacrol, and Thymol in Plant Bioassays. J Agr Food Chem. 2015; 63: 8981-8990. doi: 10.1021/acs.jafc.5b03049

9. BRASIL. Regras para Análise de Sementes. MAPA/ACS: Brasília, Brasil, 2009, 395p. 
10. Maguire, J.D.; Speed of germination - aid in selection and evaluation for seedling emergence and vigor. Crop Sci. 1962; 2: 176-177. doi: 10.2135/cropsci1962.0011183x000200020033x

11. Beauchamp, C.; Fridovich. I.; Superoxide dismutase: Improved assays and an assay applicable to acrylamide gels. Anal Biochem. 1971; 44: 276-287. doi:10.1016/0003-2697(71)90370-8

12. Giannopolitis, C.N.; Ries, S.K. Superoxide dismutases: I. Ocurrence in Higher Plants. Plant Physiol. 1977; 59: 309-314. doi: 10.1104/pp.59.2.309

13. Havir, E.A.; McHale, N.A. Biochemical and developmental characterization of multiple forms of catalase in tobacco leaves. Plant Physiol. 1987; 84: 450-455. doi:10.1104/pp.84.2.450.

14. Anderson, M.D.; Prasad, T.K.; Stewart, C.R. Changes in isozyme profiles of catalase, peroxidase, and glutathione reductase during acclimation to chilling in mesocotyls of maize seedlings. Plant Physiol. 1995; 109: 1247-1257. doi:10.1104/pp.109.4.1247

15. Nakano, Y.; Asada, K. Hidrogen peroxide is scavenged by ascorbate-specific peroxidase in spinach chloroplast. Plant Cell Physiol. 1981; 22: 867-880. doi: 10.1093/oxfordjournals.pcp.a076232 16. SAS Institute. SAS/STAT 9.1 User's Guide, SAS Institute Inc.: Cary, USA, 2004, 5513p.

17. Alves, M.C.S.; Medeiros Filho, S.; Innecco, R.; Torres, S.B. Alelopatia de extratos voláteis na germinação de sementes. Pesqui Agropecu Bras. 2004; 39: 1083-1086. doi:10.1590/S0100-204X2004001100005

18. Na, M.; Johnson, I.R.; Lovett, J.V. Mathematical modeling of allelopathy: Biological response to allelochemicals and its interpretation. J Chem Ecol. 1993; 19: 2379-2388. doi:10.1007/BF00979671 19. Colpas, F.T.; Ono, E.O.; Rodrigues, J.D.; Passos, J.R.S. Effects of some phenolic compounds on soybean seed germination and on seed-borne fungi. Braz. Arch. Biol. Technol. 2003; 46: 155-161.doi.org/10.1590/S1516-89132003000200003

20. AOSA. Seed vigour testing handbook, Contribution $n^{\circ} 32$ to the handbook on seed testing, Association of Official Seed Analysts: Springfield, USA, 1983, 88p.

21. Mello Filho, A.C.; Hoffmann, M.E.; Meneghini, R. Cell killing and DNA damage by hydrogen peroxide are mediated by intracellular iron. Biochem J. 1984; 218: 273-275.

2018 by the authors. Submitted for possible open access publication under the terms and conditions of the Creative Commons Attribution (CC BY NC) license (https://creativecommons.org/licenses/by-nc/4.0/). 